\title{
Different degrees of tolerance to hydrogen sulphide in populations of Macoma balthica (Bivalvia, Tellinidae)
}

\author{
Andreas Jahn*, Hans Theede \\ Institut für Meereskunde an der Universität Kiel, Abteilung Meereszoologie, Düsternbrooker Weg 20, D-24103 Kiel, Germany
}

\begin{abstract}
Populations of the Baltic clam Macoma balthica show different degrees of sulphide tolerance in relation to sulphide contamination of their habitats. Specimens from sulphidic habitats such as the Gulf of Gdańsk (Baltic Proper) and shallow waters near the island of Hiddensee (Southern Baltic Sea) have higher survival capacities during sulphide exposure than those from low sulphide contaminated environments such as Kiel Bight. (Western Baltic Sea) and the Wadden Sea near Dorum-Neufeld (Weser estuary, North Sea). The tolerant clams are better able to protect cytochrome coxidase against sulphide toxification. It can be assumed that this protection is due to slower sulphide diffusion into the tissues. Sulphide-tolerant specimens from hıghly sulphidic habitats have apparent sulphide diffusion coefficients which are roughly half those of sulphide-sensitive specimens from low sulphidic stations. Higher sulphide influx into the sensitive clams will negatively affect their metabolism, combined with longer inhibition of cytochrome coxidase, resulting in higher mortality.
\end{abstract}

KEY WORDS: Macoma balthica Population - Hydrogen sulphide Apparent diffusion coefficient Apparent detoxification constant Cytochrome coxidase Macrofauna Baltic Sea-North Sea

\section{INTRODUCTION}

Since the study of Fenchel \& Riedl (1970), who first described the 'sulphide system' underneath the oxidized layer of marine sand bottoms, hydrogen sulphide has been considered to be an important ecological factor for marine benthic organisms (Vismann 1991b, Giere 1992, Grieshaber et al. 1992). In most cases, free oxygen diffuses only a few mm into shallow coastal marine sediments with a high organic load (Revsbech et al. 1980, Meyers et al. 1987, Giere 1992). In the anoxic sediment layers, production of hydrogen sulphide occurs by dissimilatory sulphate reduction (Jørgensen \& Fenchel 1974, Jørgensen 1977, 1990, Huxtable 1986, Widdel 1988). Particularly in the Baltic Sea, with its thermohaline stratification, oxygen deficiency is found regularly at the bottom of deeper trenches (Weigelt 1990, 1991, Babenerd 1991). Even shallow areas have become increasingly exposed to hypoxic conditions combined with high sulphide con-

•E-mail: ajahn@ifm.unı-kiel.de centrations caused e.g. by drifting algal mats due to increasing anthropogenic eutrophication (Prena 1994. Norkko \& Bonsdorff 1996).

The term 'sulphide' refers to total reduced sulphur, i.e. the sum of $\mathrm{H}_{2} \mathrm{~S}, \mathrm{HS}^{-}$, and $\mathrm{S}^{2-}$. Due to its neutral charge, undissociated $\mathrm{H}_{2} \mathrm{~S}$ diffuses easily through biological membranes (Powell 1989, Julian \& Arp 1992). In the mitochondria it inhibits the last enzymatic reaction of the respiratory chain by forming a stable complex with cytochrome $c$ oxidase. This leads to a total breakdown of the oxidative metabolism (Nicholls 1975, Nicholls \& Kim 1981, 1982)

Thus, hydrogen sulphide is a toxicant which occurs regularly in marine habitats. It has been known for a long time that several species with high levels of tolerance to oxygen deficiency are able to survive under sulphidic conditions (Theede et al. 1969, Theede 1973). During recent years our knowledge of ecological adaptations to hydrogen sulphide has been extended (reviews: Somero et al. 1989. Vismann 1991b, Bagarinao 1992). Invertebrates from sulphidic habitats show species-specific adaptations to hydrogen sulphide. 
Most important among these is the detoxification of hydrogen sulphide by oxidation (Vismann 1991a, Jahn et al. 1992, 1993, 1996, 1997, Oeschger \& Vetter 1992, Völkel \& Grieshaber 1992, Hagerman \& Vismann 1993, Johns et al. 1997).

Differences in detoxification capacities may be related to sulphide tolerance of the species and may have important ecological implications. Vismann (1990) found a distinctly higher tolerance to oxygen deficiency and hydrogen sulphide as well as higher sulphide oxidation activity in the nereid polychaete Hediste (Nereis) diversicolor in comparison to Neanthes (Nereis) virens. This higher tolerance allows $H$ diversicolor to stay in sediment patches where exposure to sulphide is too high for $N$. virens. The significance of hydrogen sulphide as an ecological factor for the distribution of nereid polychaetes was also stated by Miron \& Kristensen (1993a, b). The differences in sulphide tolerance could be based on different sulphide oxidation capacities of mitochondria. Isolated mitochondria of the sulphide-tolerant species $H$. diversicolor and Neanthes (Nereis) succinea showed higher sulphide oxidation ratos in comparison to the suiphide-sensitive species $N$. virens and Nereis pelagica (Oeschger \& Tschischka 1995, Tschischka \& Oeschger 1995).

In the polychaete species complex Capitella capitata, Gamenick \& Giere (1994) found 2 different sized forms in intertidal flats of the North Sea which differ distinctly in their tolerance to hypoxia and sulphide. The authors characterized these as sibling species of $C$. capitata, which was confirmed by electrophoretical studies (Gamenick \& Giere 1996). Different sulphide tolerances were also found in the congeneric clams Macoma secta and Macoma nasuta (Levitt \& Arp 1991). However, different degrees of sulphide tolerance at the population level are practically unknown. To date, this was only reported for populations of the echiuran Urechis caupo (Arp et al. 1992).

Many species occur in sulphidic as well as in nonsulphidic habitats, so that differences in sulphide tolerance of the populations are a possibility. The Baltic clam Macoma balthica (L.) is one of the most important macrozoobenthic species in the Baltic and the North Sea (Beukema \& Meehan 1985, Günther 1991, Bonsdorff et al. 1995). It dominates especially in habitats characterized by a high sulphide contamination (Janas \& Szaniawska 1996, Włodarska-Kowalczuk et al. 1996, Jahn et al. 1997) but is also found in well-oxygenated sediments (Jahn et al. 1993, Jahn 1997). The aim of this study was to investigate the sulphide tolerance and its background in different populations of $M$. balthica.

\section{MATERIAL AND METHODS}

Animals. Specimens of Macoma balthica, living in about $5 \mathrm{~cm}$ sediment depth, were collected from 1 station in the North Sea and 3 in the Baltic (Fig. 1): (1) the Wadden Sea near Dorum-Neufeld (Weser estuary), 0 to $1 \mathrm{~m}$ depth; (2) Kiel Bight (Western Baltic Sea), $54^{\circ} 32.1^{\prime} \mathrm{N}, 10^{\circ} 20.9^{\prime} \mathrm{E}, 12 \mathrm{~m}$ depth; (3) Hiddensee Island near Rügen (Southern Baltic Sea), 0.3 to $1 \mathrm{~m}$ depth; (4) Gulf of Gdańsk (Baltic Proper), 54³4.2' N, $18^{\circ} 48.6^{\prime} \mathrm{E}, 60 \mathrm{~m}$ depth. In Kiel Bight and the Gulf of Gdańsk clams were collected with a Van Veen grab

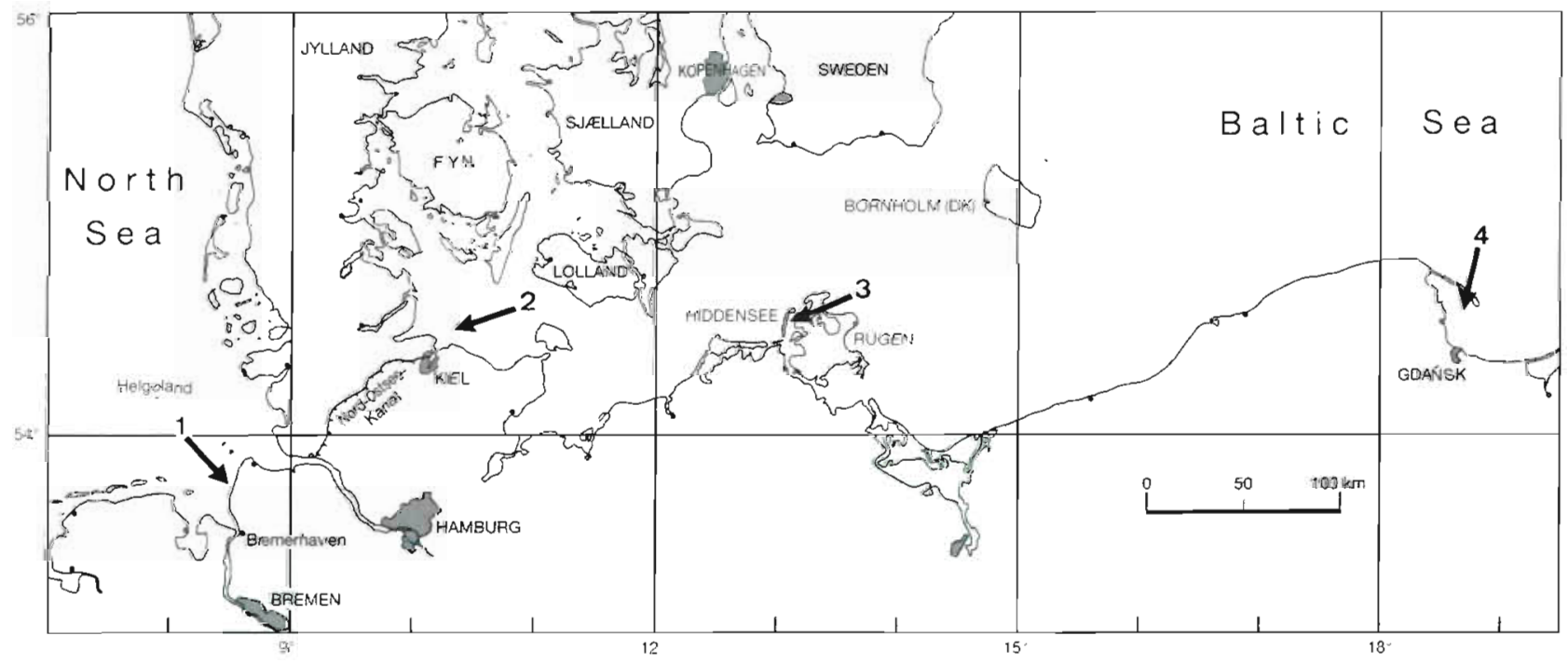

Fig. 1 Location of sampling stations: (1) Dorum-Neufeld (0-1 m depth), (2) Kiel Bight (12 m depth), (3) Hiddensee (0.3-1 m depth), (4) Gulf of Gdańsk (60 m depth). Based on sea map No. 2613 'North and Baltic Sea'; original scale 1:2 100000; by authorization of Bundesamt für Seeschiffahrt und Hydrographie, Hamburg and Rostock -8095.02/97 Z1101 
or with a rectangular dredge. At the coastal stations Dorum-Neufeld and Hiddensee clams were dug up and sifted through a sieve of $0.5 \mathrm{~cm}$ mesh size. Average shell lengths of the clams were $15.9 \pm 2.1 \mathrm{~mm}$ (DorumNeufeld), $12.6 \pm 1.1 \mathrm{~mm}$ (Kiel Bight), $15.3 \pm 2.3 \mathrm{~mm}$ (Hiddensee), and $15.3 \pm 1.5 \mathrm{~mm}$ (Gulf of Gdańsk; $\mathrm{n}=$ 20 each). The bivalves were kept in aquaria with natural sediment and aerated seawater at a temperature of $5^{\circ} \mathrm{C}$ and a salinity of $22 \% \mathrm{~S}$ for Dorum-Neufeld and Kiel Bight or $9 \%$ S for Hiddensee and the Gulf of Gdańsk until use for experiments. One day before each experiment, clams were acclimated to the experimental temperature of $10^{\circ} \mathrm{C}$.

Abiotic factors at the sampling stations. Salinity in the water at the sampling stations was measured by using a conductometer (LF 191, WTW, Germany). Oxygen content was determined with an oximeter (Oxi 191, WTW) or by the Winkler method. Sulphide was analysed by extracting sediment pore water with handmade samplers (after Howes et al. 1985) or by centrifuging sediment segments at $14500 \times \mathrm{g}$ for $3 \mathrm{~min}$ (Janas \& Szaniawska 1996). Sulphide concentration in the collected pore water was determined photometrically according to Cline (1969).

Experimental incubations. Specimens of Macoma balthica were incubated under hypoxic, hypoxic-sulphidic, and oxic-sulphidic conditions. The medium for hypoxic incubations was prepared by bubbling pure nitrogen through seawater (Dorum-Neufeld, Kiel Bight: $22 \%$ S; Hiddensee, Gulf of Gdańsk: $9 \%$ S) in a glass cylinder for at least $1 \mathrm{~h}$. After this procedure, oxygen content was lower than $5 \%$ of air saturation (controlled by the Winkler method). For hypoxic-sulphidic experiments, oxygen-deficient seawater $(300 \mathrm{ml})$ was carefully transferred through a tube into a glass flask containing crystals of $\mathrm{Na}_{2} \mathrm{~S} \cdot 9 \mathrm{H}_{2} \mathrm{O}$, leading to a final sulphide concentration of $100 \mu \mathrm{M}$. Sulphide concentration was measured photometrically (Cline 1969). Before starting the experiment, $\mathrm{pH}$ was adjusted to 8.0. About 30 clams were placed into the flask, sealed with argon, and kept at $10^{\circ} \mathrm{C}$ for different periods of time. Due to sulphide oxidation during incubation, sulphide concentration and $\mathrm{pH}$ were adjusted several times per day. To avoid the accumulation of toxic metabolites (Levitt \& Arp 1991), the medium was exchanged every 3 to $4 \mathrm{~d}$. During the same time, oxygen concentration was measured using the modified method of oxygen determination according to Ingvorsen \& Jargensen (1979)

Oxic-sulphidic incubations $\left(\mathrm{O}_{2}>50 \%\right.$ air saturation) were carried out by using a flow-through system. An incubation chamber made of glass (volume ca 0.5 l) containing about 30 clams was connected via peristaltic pumps to a sulphide stock solution $15 \mathrm{mM}$ sulphide; 22 or $9 \% \mathrm{~S}$; pH 8.0; sealed with a balloon with argon) and oxygenated seawater (22 or $9 \% \mathrm{~S}$; bubbled with air). Adjusting the pumps led to a final sulphide concentration of 100 or $200 \mu \mathrm{M}$. Flowthrough rate was about $0.5 \mathrm{l} \mathrm{h}^{-1}$ The experimental set up was placed in a temperature constant room at $10^{\circ} \mathrm{C}$. During the experiments, $\mathrm{pH}$, oxygen (according to Ingvorsen \& Jørgensen 1979), and sulphide concentrations (according to Cline 1969) were regularly monitored.

Tolerance experiments. In order to study the survival of Macoma balthica, specimens from the different populations were incubated under hypoxic, hypoxicsulphidic, and oxic-sulphidic conditions and checked once per day. Mortality assessment was based on failure of constriction when touching an open clam. Dead clams were removed from the chambers.

Activity of cytochrome $c$ oxidase. Activity of cytochrome $c$ oxidase in the tissues was measured according to Hand \& Somero (1983). Cut tissue samples (ca $1 \mathrm{~g}$ ) were homogenized in $10 \mathrm{ml}$ potassium phosphate buffer (20 mM; pH 7.4) using an electrical homogenizer (Heidolph, Germany; $300 \mathrm{rpm}$ ) and centrifuged at $2000 \times \mathrm{g}$ and $0^{\circ} \mathrm{C}$ for $15 \mathrm{~min}$. The pellet was washed with homogenization buffer and centrifuged again. The supernatants of both centrifugations were combined, adjusted to $\mathrm{pH} 5.6$ with acetic acid (1 M), and then centrifuged at $5000 \times \mathrm{g}$ and $0^{\circ} \mathrm{C}$ for $15 \mathrm{~min}$. The resulting pellet was resuspended in $500 \mu \mathrm{l}$ homogenization buffer

In order to prepare substrate for the enzyme, $25 \mathrm{mg}$ cytochrome $\mathrm{c}$ was dissolved in $2 \mathrm{ml}$ oxygen-free potassium phosphate buffer (10 mM; pH 7.0; 1 mM EDTA) and reduced by adding trace amounts of sodium dithionite. Excess of dithionite and its breakdown and reaction products were removed by gel sieving. For this purpose, sephadex G-25 was equilibrated with potassium phosphate buffer $(10 \mathrm{mM} ; \mathrm{pH} 7.0 ; 1 \mathrm{mM}$ EDTA), filled in small syringes, and centrifuged at $2000 \times \mathrm{g}$ and $0^{\circ} \mathrm{C}$ for $2 \mathrm{~min}$. Then, $500 \mu \mathrm{l}$ of the cytochrome $c$ solution was added to the top of one syringe containing equilibrated $\mathrm{G}-25$ and centrifuged at $2000 \times g$ and $0^{\circ} \mathrm{C}$ for $2 \mathrm{~min}$. The purified solutions, sealed with argon, could be stored for several days at $-15^{\circ} \mathrm{C}$ (Hand \& Somero 1983).

Enzyme activity of tissue samples was measured photometrically at $550 \mathrm{~nm}$ by using $500 \mu \mathrm{l}$ potassium phosphate buffer (200 mM; pH 6.0; 1 mM EDTA), $50 \mu \mathrm{l}$ cytochrome $c$ solution as substrate, and distilled water to a final volume of $1000 \mu$. Enzyme reaction was started with a 10 to $100 \mu$ sample. Activity was normalised to protein content of the samples (Bradford 1976).

The apparent inhibition constant $\left(K_{\mathrm{l}}\right)$ for sulphide was calculated from enzyme activity at different sulphide concentrations by using a computer program. according to Job et al. (1978). 
Concentrations of sulphide, thiosulphate, sulphite, and elemental sulphur in the tissues. After incubation, sulphide content in the tissues and its oxidation products thiosulphate and sulphite were estimated by High-Performance Liquid Chromatography (HPLC) by derivatization with monobromobimane (Newton et al. 1981, Vetter et al. 1989, Jahn et al. 1996, Jahn 1997).

Only reduced sulphur compounds are detectable using the bimane method. Therefore, the concentration of elemental sulphur, which consists mainly of cyclic octamers ( $\mathrm{S}_{y ;}$ Steudel et al. 1987, 1988), was analysed according to Lauren \& Watkinson (1985). The tissues were deep frozen and ground in liquid nitrogen, homogenized in $200 \mu \mathrm{l}$ ice-cold chloroform, and shaken for $20 \mathrm{~h}$ at $\sim 0^{\circ} \mathrm{C}$. After short centrifugation $(-10000 \times g)$, $20 \mu \mathrm{l}$ of the supernatant were separated by KontronHPLC equipment (Data System 450-MT, Germany). A PRP-1 reversed-phase column (Hamilton, USA; $15 \mathrm{~cm}$ ) was used. The mobilc phase was methanol-chloroform (50.50) at $1.5 \mathrm{ml} \mathrm{min}^{-1}$ for $5.5 \mathrm{~min}$. Chromatograms were detected at $254 \mathrm{~nm}$. Standards were prepared by solving $25.648 \mathrm{mg}$ sulphur $\left(100 \mu \mathrm{mol} \mathrm{S}_{8}\right)$ in $100 \mathrm{ml}$ icecold chloroform. After shaking for $20 \mathrm{~h}$ at $\sim 0^{\circ} \mathrm{C}, 20$ ul $(\triangleq 20 \mathrm{nmol} \mathrm{S}$ ) were diluted with $180 \mu \mathrm{l}$ chloroform, and $20 \mu \mathrm{l}\left(\triangleq 2000 \mathrm{pmol} \mathrm{S}_{8}\right)$ were injected. Detection limit was about 10 pmol $\mathrm{S}_{8}$.

Statistics. Data are given as means with standard deviation (SD). Their significance was analysed using the nonparametric $U$-test of Mann \& Whitney with a significance level of $5 \%$.

Apparent diffusion coefficients and apparent detoxification constants for sulphide. Apparent diffusion coefficients and apparent detoxification constants for total sulphide for the different populations of Macoma balthica were determined using the model described. in detail in Jahn (1997) and Jahn et al. (1996, 1997) with the following equations:

$$
\begin{aligned}
D & =\frac{r_{e}^{2}}{3 \tau} \\
r_{\mathrm{e}} & =\sqrt[3]{\frac{3}{4} \frac{w m}{\rho \pi}} \\
\frac{1}{C} & =\frac{\tau}{c_{0}} \frac{1}{t}+\frac{1}{C_{0}} \\
k & =\frac{1}{\tau} \ln \frac{C_{0}}{c_{1}}
\end{aligned}
$$

where $D=$ apparent diffusion coefficient $r_{\mathrm{e}}=$ effective radius; $\tau=$ half-saturation time; $w=$ tissue water content; $m=$ fresh mass; $\rho=$ density of water; $c=$ total sulphur concentration; $c_{0}=$ external sulphide concentration; $t=$ incubation time; $k=$ apparent detoxification constant; and $C_{i}=$ internal sulphide equilibrium concentration.
Table 1 Concentration of hydrogen sulphide (minimummaximum; June 1992 to May 1995) in pore water at $5 \mathrm{~cm}$ sediment depth as well as oxygen content and salinity of the water column. For position of sampling stations see Fig. 1

\begin{tabular}{lccc|}
\hline Station & $\begin{array}{c}\text { Sulphide } \\
{[\mu \mathrm{M}]}\end{array}$ & $\begin{array}{c}\text { Oxygen } \\
{[\% \text { sat.] }}\end{array}$ & $\begin{array}{c}\text { Salinity } \\
{[\% \text { S] }}\end{array}$ \\
\hline Dorum & $4-11$ & & 22 \\
Kiel & $1-13$ & 95 & 15 \\
Hiddensee & $1-432$ & 84 & 10 \\
Gdańsk & $5-193$ & 83 & 7 \\
\hline
\end{tabular}

\section{RESULTS}

\section{Sediment sulphide concentrations at the sampling stations}

Macoma balthica is exposed in its habitats to different concentrations of hydrogen sulphide (Table 1). The stations Dorum-Neufeld in the German Wadden Sea and Kiel Bight (Western Baltic Sea) were only slightly contaminated with sulphide, even in sumuner. On the other hand, sulphide concentrations of around $200 \mu \mathrm{M}$ could be found in sediment pore water in the Gulf of Gdańsk (Baltic Proper). In shallow habitats close to the island of Hiddensee (Southern Baltic Sea), sulphide concentrations in the sediment reached almost $500 \mu \mathrm{M}$ in summer. Due to high spatial and temporal variations, Table 1 shows only minima and maxima instead of mean values.

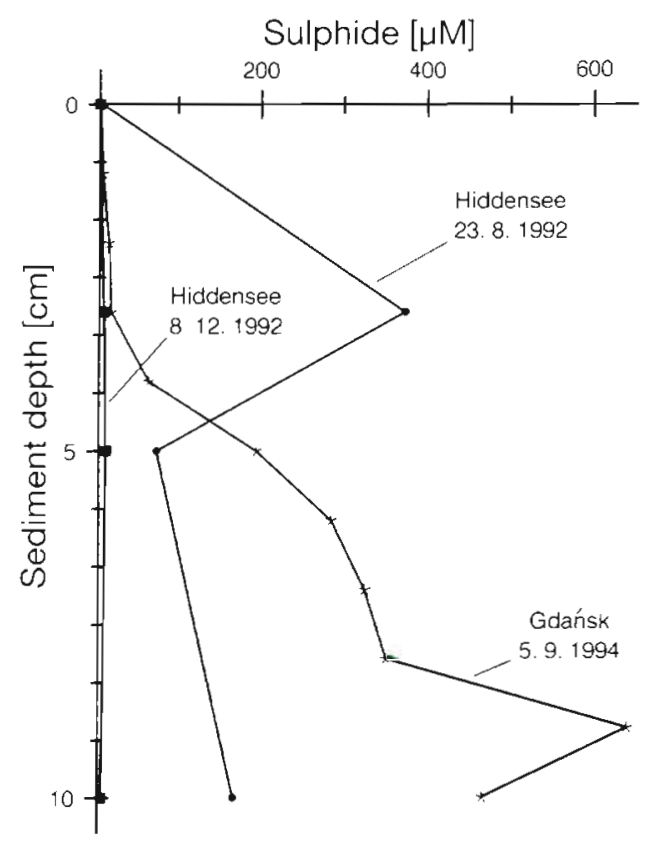

Fig. 2. Concentrations of hydrogen sulphide in pore water of the sediment of the sampling stations at Hiddensee (23 August 1992 and 8 December 1992) and the Gulf of Gdańsk (5 September 1994) 
Sulphide concentrations also varied with sediment depth. Whereas at Hiddensee maximum concentration occurred at a sediment depth of $3 \mathrm{~cm}$, maxima in the Gulf of Gdańsk were found in deeper parts of the sediment. Just as an example, Fig. 2 shows 3 sediment profiles.

\section{Tolerance experiments}

Tolerance to oxygen deficiency and hydrogen sulphide was tested with specimens of the studied populations of Macoma balthica. There were no differences in lethal times of $50 \%$ of the individuals $\left(\mathrm{LT}_{50}\right)$ under hypoxia (Fig 3a) or under hypoxic-sulphidic conditions (Fig. 3b). In all cases, $\mathrm{LT}_{50}$ at $10^{\circ} \mathrm{C}$ were about 8 to $12 \mathrm{~d}$. However, if oxygen was available, the popula-
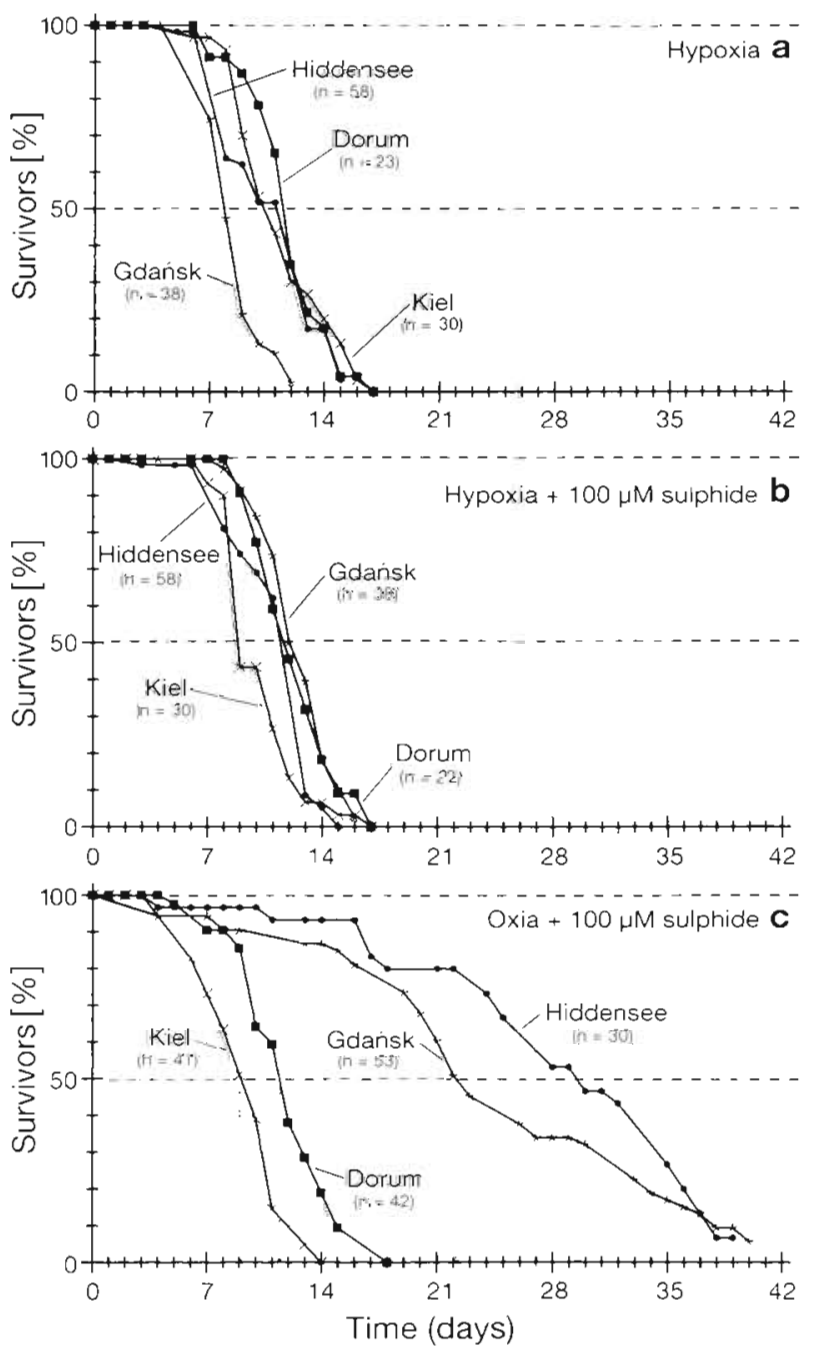

Fig. 3. Macoma balthica. Populations from Kiel Bight ( $22 \%$ S), Dorum-Neufeld ( $22 \%$ S), the Gulf of Gdańsk ( $9 \%$ S), and Hiddensee $(9 \%$ S). Survival capacity during (a) hypoxia, (b) hypoxic incubation at $100 \mu \mathrm{M}$ sulphide, and (c) oxic incubation at $100 \mu \mathrm{M}$ sulphide $\left(10^{\circ} \mathrm{C}\right)$ tions showed distinct differences in their tolerance to hydrogen sulphide (Fig. 3c). Whereas $L_{50}$ of specimens from Kiel Bight and Dorum-Neufeld were also only about 9 to $12 \mathrm{~d}, 50 \%$ of the clams from the Gulf of Gdańsk and Hiddensee survived under the same conditions for about $3 \mathrm{wk}$, and even $4 \mathrm{wk}$, respectively.

\section{Cytochrome $c$ oxidase}

When cytochrome $c$ oxidase tissue extracts from specimens of different Macoma balthica populations were tested, this enzyme was inhibited at very low concentrations of hydrogen sulphide (Table 2). Apparent sulphide inhibition constants $\left(K_{\mathrm{l}}\right)$ were at the nanomolar level in all cases.

However, enzyme activities were different when assayed after oxic-sulphidic incubations of living specimens. Specific activity decreased significantly during the first days of incubation of sulphide-sensitive clams from Kiel Bight and Dorum-Neufeld (Fig. 4a), whereas cytochrome $c$ oxidase from sulphide-tolerant clams of the Gulf of Gdańsk and Hiddensee remained active during the whole experiment of $9 \mathrm{~d}$ (Fig. 4b).

In order to study the recovery of cytachrome $c$ oxidase activity, clams from Kiel Bight and DorumNeufeld were preincubated under oxic-sulphidic conditions for $5 \mathrm{~d}$. Subsequently, the medium was replaced by normoxic seawater without sulphide. The specific activity recovered only slowly in the clams of both populations (Fig. 5). The initial level of activity was not yet completely attained after $9 \mathrm{~d}$.

\section{Sulphide oxidation}

In order to study the capacity of sulphide oxidation, specimens of Macoma balthica from the different habitats were incubated under hypoxic-sulphidic and oxicsulphidic conditions. Exposure to hypoxia with $200 \mu \mathrm{M}$ sulphide caused significant increases of sulphide con-

Table 2. Macoma balthica. Populations from Kiel Bight, Dorum-Neufeld, the Gulf of Gdansk, and Hiddensee. Apparent sulphide inhibition constant of cytochrome coxidase $\left(K_{1}\right)$ as sulphide concentrations in $\mu \mathrm{M}$ leading to $50 \%$ inhubition $(\mathrm{n}=$ 3 with various measurements between 0.1 and $5 \mu \mathrm{M}$ sulphide each

\begin{tabular}{|lc|}
\hline Population & $K_{1}[\mu \mathrm{M}$ sulphide $]$ \\
\hline Kiel & $0.65 \pm 0.41$ \\
Dorum & $0.56 \pm 0.22$ \\
Gdańsk & $0.25 \pm 0.02$ \\
Hiddensee & $0.13 \pm 0.01$ \\
\hline
\end{tabular}




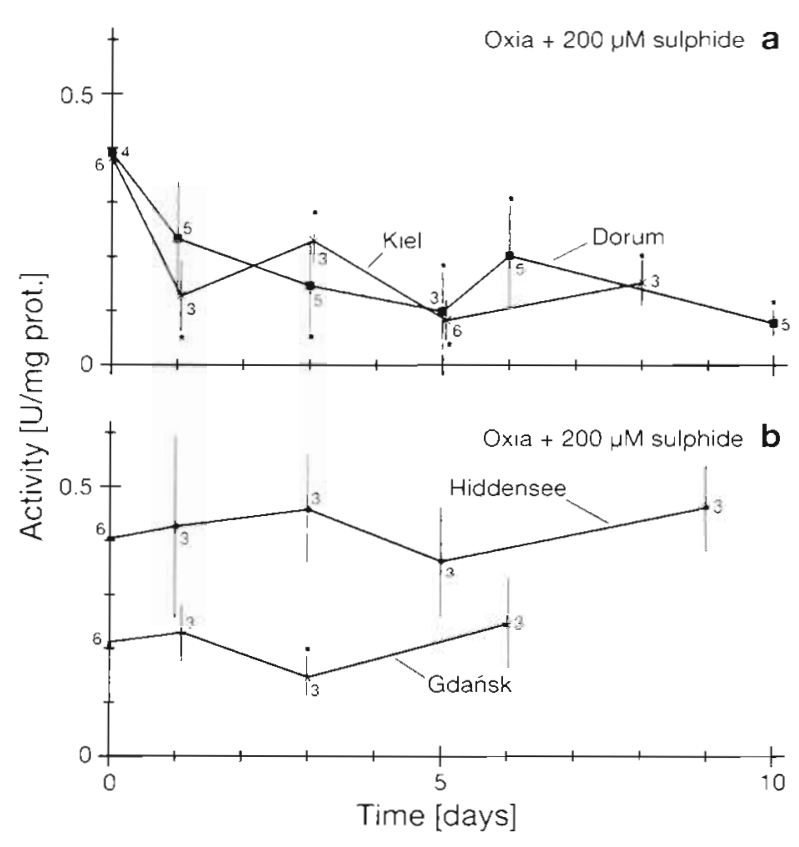

Fig. 4. Macoma balthica. Populations from (a) Kiel Bight and Dorum-Neufeld (22\% S) and from (b) the Gulf of Gdanisk and Ficduensee $(9 \%$ S). Specific activity of cytochrome $c$ oxidase during oxic incubation at $200 \mu \mathrm{M}$ sulphide $\left(10^{\circ} \mathrm{C}\right)$ in units $\mathrm{mg}^{-1}$ protein $\pm \mathrm{SD}$ (number of replicates). "Significant difference to control $(p \leq 0.05)$

centrations in the tissues of clams from all studied populations (Fig. 6a, Table 3). Especially the sulphidesensitive clams from Kiel Bight showed a high accumulation of sulphide (Fig. 6a, Table 3a). At hypoxia, only low concentrations of sulphide oxidation products such as thiosulphate (Fig. 6b), sulphite, and elemental sulphur were found (Table 3).

If oxygen was available, Macoma balthica was able to oxidize penetrated sulphide, leading to lower sulphide concentrations in the tissues (Fig. $7 \mathrm{a}$, Table 3). Thiosulphate was the main oxidation product (Fig. $7 \mathrm{~b}$ ).

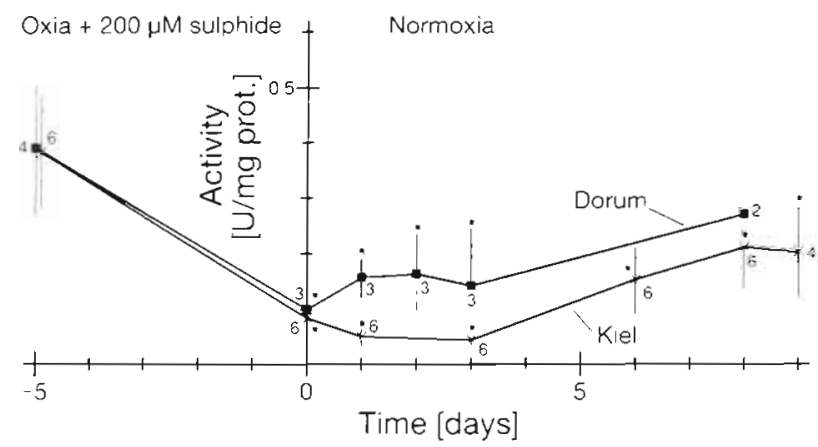

Fig. 5. Macoma balthica. Populations from Kiel Bight and Dorum-Neufeld. Recovery of specific activity of cytochrome $c$ oxidase. Clams were incubated with $200 \mu \mathrm{M}$ sulphide under oxic conditions for $5 \mathrm{~d}$ and then kept at normoxic conditions without sulphide $\left(10^{\circ} \mathrm{C} ; 22 \%\right.$ S). For further detalls see Fig. 4

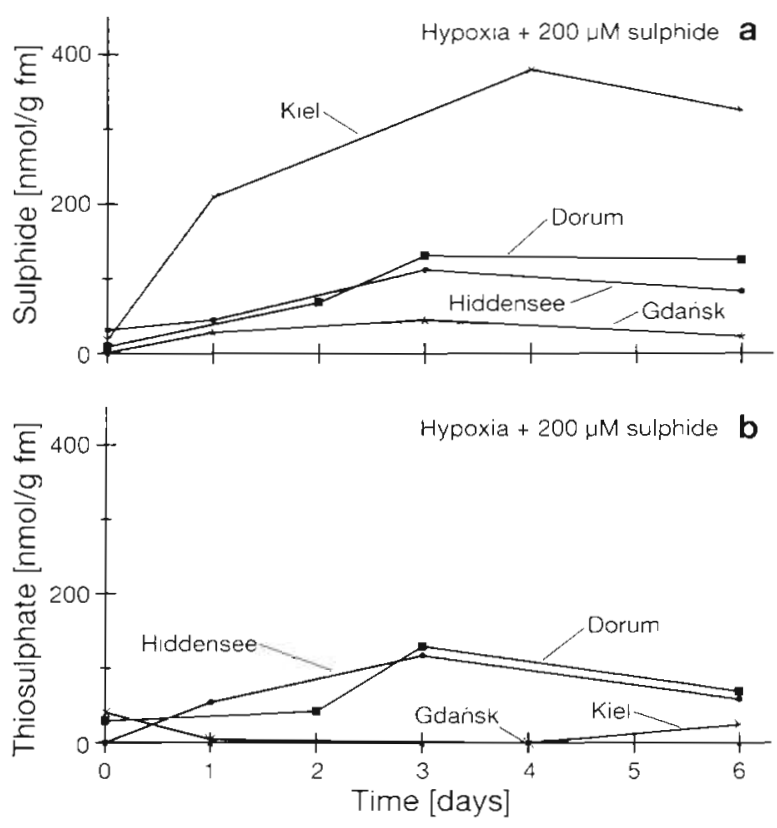

Fig. 6. Macoma balthica. Populations from Kiel Bight, DorumNeufeld, the Gulf of Gdańsk and Hiddensee. Concentrations of (a) sulphide and (b) thiosuiphate in the lissues diter hypoxic incubation at $200 \mathrm{\mu M} \mathrm{H}_{2} \mathrm{~S}$. For further details see Table 3

In specimens of all studied populations a significant increase of thiosulphate concentration in the tissues was detectable. The production of sulphite and elemental sulphur was of minor importance (Table 3 ).
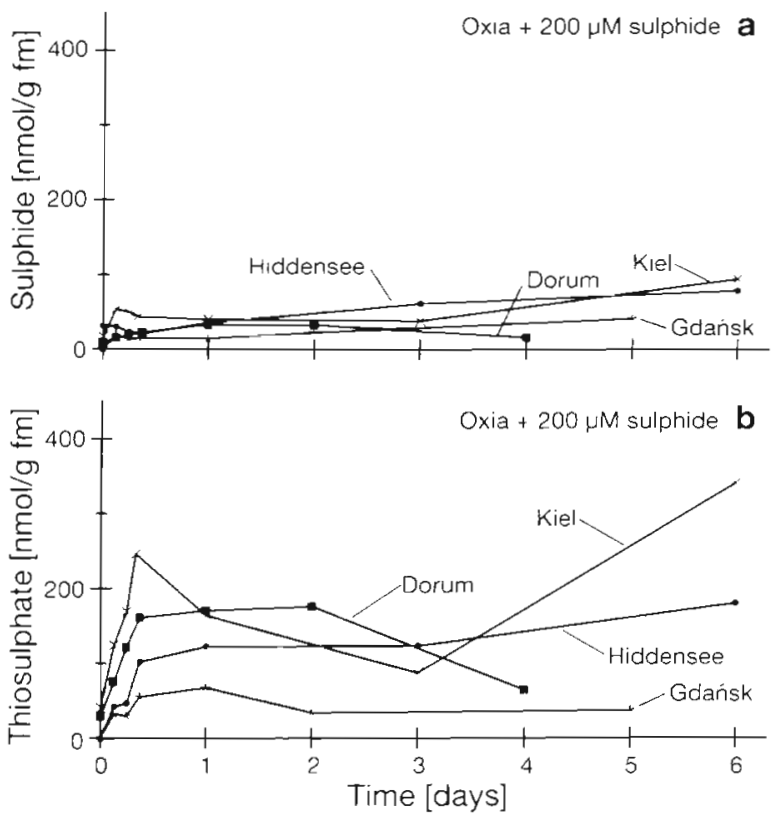

Fig. 7. Macoma balthica. Populations from Kiel Bight, DorumNeufeld, the Gulf of Gdansk and Hiddensee. Concentrations of (a) sulphide and (b) thiosulphate in the tissues after oxic incubation at $200 \mu \mathrm{M} \mathrm{H}_{2} \mathrm{~S}$. For further details see Table 3 
Table 3. Macoma balthica. Populations from (a) Kiel Bight, (b) Dorum-Neufeld (c) Gulf of Gdańsk and (d) Hiddensee. Concentrations of sulphide, thiosulphate sulphite, and elemental sulphur in the tissues after hypoxic and oxic incubation

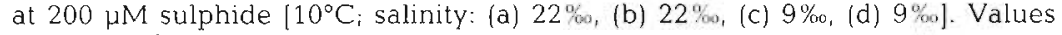
in nmol g ${ }^{-1}$ fresh mass $\pm \mathrm{SD}$ (number of replicates). 'Significant difference to control $(p \leq 0.05)$

\begin{tabular}{|c|c|c|c|c|}
\hline Incubation & $\begin{array}{c}\text { Sulphide } \\
{\left[\mathrm{nmol} \mathrm{g}^{-1} \mathrm{fm}\right]}\end{array}$ & $\begin{array}{l}\text { Thiosulphate } \\
{\left[\mathrm{nmol} \mathrm{g}^{-1} \mathrm{fm}\right]}\end{array}$ & $\begin{array}{c}\text { Sulphite } \\
{\left[\mathrm{nmol} \mathrm{g}^{-1} \mathrm{fm}\right]}\end{array}$ & $\begin{array}{c}\text { Sulphur } \\
{\left[\mathrm{nmolg}^{-1} \mathrm{fm}\right]}\end{array}$ \\
\hline \multicolumn{5}{|l|}{ (a) Kiel Bight } \\
\hline Control & $17 \pm 6(5)$ & $41 \pm 4(5)$ & $0 \pm 0(5)$ & $10 \pm 7(10)$ \\
\hline $1 \mathrm{~d}$ hypoxic & $209 \pm 87(5)^{\circ}$ & $5 \pm 11(5)$ & $66 \pm 67(5)$ & $7 \pm 8\{5\}$ \\
\hline 3 d hypoxic & & & & $65 \pm 83(5)$ \\
\hline 4 d hypoxic & $379 \pm 66(5)^{\circ}$ & $0 \pm 0(5)$ & $119 \pm 110(5)^{\circ}$ & \\
\hline $6 \mathrm{~d}$ hypoxic & $325 \pm 53(4)^{\circ}$ & $24 \pm 19(4)$ & $51 \pm 74(4)$ & $13 \pm 6(6)$ \\
\hline 3 h oxic & $54 \pm 27(5)^{\circ}$ & $124 \pm 99(5)^{\circ}$ & $0 \pm 0(5)$ & $17 \pm 8\{4\}$ \\
\hline 6 h oxic & $50 \pm 14(5)^{\circ}$ & $169 \pm 107(5)$ & $0 \pm 0(5)$ & $28 \pm 18(5)^{\circ}$ \\
\hline 8 h oxic & $44 \pm 8(5)^{\circ}$ & $246 \pm 102(5)^{\circ}$ & $0 \pm 0(5)$ & $26 \pm 23(4)$ \\
\hline $1 \mathrm{~d}$ oxic & $40 \pm 15(9)^{\circ}$ & $164 \pm 76(9)^{\circ}$ & $0 \pm 0(9)$ & $19 \pm 4(5)^{\circ}$ \\
\hline $3 \mathrm{~d}$ oxic & $38 \pm 19(5)^{\circ}$ & $87 \pm 45(5)$ & $0 \pm 0(5)$ & $27 \pm 10(5)^{\circ}$ \\
\hline $6 \mathrm{~d}$ oxic & $94 \pm 9(5)^{\circ}$ & $340 \pm 125(5)^{\circ}$ & $0 \pm 0(5)$ & $38 \pm 17(6)^{\circ}$ \\
\hline \multicolumn{5}{|c|}{ (b) Dorum-Neufeld } \\
\hline Control & $9 \pm 10(8)$ & $29 \pm 30(8)$ & $0 \pm 0(8)$ & $19 \pm 19(5)$ \\
\hline $1 \mathrm{~d}$ hypoxic & & & & $2 \pm 3(5\}$ \\
\hline $2 \mathrm{~d}$ hypoxic & $69 \pm 29(5)^{*}$ & $43 \pm 21(5)$ & $238 \pm 236(5)^{\circ}$ & \\
\hline 3 d hypoxic & $131 \pm 52(5)^{\circ}$ & $130 \pm 45(5)^{\circ}$ & $0 \pm 0(5)$ & $8 \pm 9(5)$ \\
\hline 6 d hypoxic & $125 \pm 91(4)^{\circ}$ & $69 \pm 53(4)$ & $187 \pm 217(4)$ & $8 \pm 10(5)$ \\
\hline 3 h oxic & $16 \pm 7(4)$ & $75 \pm 28(4)^{\circ}$ & $0 \pm 0(4)$ & \\
\hline 6 h oxic & $20 \pm 8(4)$ & $121 \pm 83(4)^{\circ}$ & $0 \pm 0(4)$ & \\
\hline 9 h oxic & $23 \pm 16(5)$ & $161 \pm 106(5)^{\circ}$ & $0 \pm 1(5)$ & \\
\hline $1 \mathrm{~d}$ oxic & $33 \pm 29(9)^{\circ}$ & $170 \pm 195(9)^{\circ}$ & $4 \pm 6(9)$ & \\
\hline $2 \mathrm{~d}$ oxic & $33 \pm 37(5)$ & $176 \pm 132(5)^{\circ}$ & $20 \pm 29(5)$ & \\
\hline $4 \mathrm{~d}$ oxic & $16 \pm 6(3)$ & $64 \pm 14(3)^{\circ}$ & $19 \pm 33(3)$ & \\
\hline \multicolumn{5}{|c|}{ (c) Gulf of Gdańsk } \\
\hline Control & $1 \pm 2(5)$ & $0 \pm 0(5)$ & $0 \pm 0(5)$ & $12 \pm 9(10)$ \\
\hline $1 \mathrm{~d}$ hypoxic & $28 \pm 10(5)^{\circ}$ & $0 \pm 0(5)$ & $0 \pm 0(5)$ & $21 \pm 37(5)$ \\
\hline 3 d hypoxic & $45 \pm 36(5)^{\circ}$ & $0 \pm 0(5)$ & $0 \pm 0(5)$ & $11 \pm 8(5)$ \\
\hline 6 d hypoxic & $23 \pm 14(4)^{\circ}$ & $0 \pm 0(4)$ & $0 \pm 0(4)$ & $23 \pm 16(7)$ \\
\hline 3 h oxic & $19 \pm 16(5)^{\circ}$ & $32 \pm 27(5)^{\circ}$ & $0 \pm 0(5)$ & \\
\hline 6 h oxic & $14 \pm 11(5)^{\circ}$ & $30 \pm 26(5)^{\circ}$ & $0 \pm 0(5)$ & \\
\hline 9 h oxlc & $15 \pm 6(5)^{\circ}$ & $55 \pm 34(5)^{\circ}$ & $0 \pm 0(5)$ & \\
\hline $1 \mathrm{~d}$ oxic & $15 \pm 12(10)^{\circ}$ & $68 \pm 80(10)^{\circ}$ & $0 \pm 0(10)$ & $15 \pm 8(5)$ \\
\hline 2 d oxic & $23 \pm 16(5)^{\circ}$ & $34 \pm 25(5)^{\circ}$ & $0 \pm 0(5)$ & \\
\hline $3 \mathrm{~d}$ oxic & & & & $31 \pm 42(3)$ \\
\hline $5 \mathrm{~d}$ oxic & $41 \pm 23(5)^{\circ}$ & $37 \pm 25(5)^{\circ}$ & $0 \pm 0(5)$ & \\
\hline $6 \mathrm{~d}$ oxic & & & & $35 \pm 12(4)^{\circ}$ \\
\hline \multicolumn{5}{|c|}{ (d) Hiddensee } \\
\hline Control & $31 \pm 10(5)$ & $0 \pm 0(5)$ & $0 \pm 0(5)$ & $10 \pm 6(10)$ \\
\hline $1 \mathrm{~d}$ hypoxic & $45 \pm 27(5)$ & $54 \pm 37(5)^{\circ}$ & $0 \pm 0(5)$ & $7 \pm 7(5)$ \\
\hline $3 \mathrm{~d}$ hypoxic & $112 \pm 46(5)^{\circ}$ & $117 \pm 77(5)^{\circ}$ & $0 \pm 0(5)$ & $11 \pm 9(5)$ \\
\hline $6 \mathrm{~d}$ hypoxic & $83 \pm 13(5)^{\circ}$ & $58 \pm 24(5)^{\circ}$ & $0 \pm 0(5)$ & $22 \pm 12(6)^{\circ}$ \\
\hline 3 h oxic & $30 \pm 14(5)$ & $42 \pm 38(5)^{\circ}$ & $0 \pm 0(5)$ & $20 \pm 20(5)$ \\
\hline $6 \mathrm{~h} \mathrm{oxic}$ & $23 \pm 8(5)$ & $46 \pm 30(5)^{\circ}$ & $0 \pm 0(5)$ & $12 \pm 8(5)$ \\
\hline 9 h oxic & $21 \pm 8(5)$ & $102 \pm 33(5)^{*}$ & $0 \pm 0\{5\}$ & $17 \pm 7(5)$ \\
\hline $1 \mathrm{~d}$ oxic & $36 \pm 23(10)$ & $122 \pm 119(10)^{\circ}$ & - $\quad 0 \pm 0(10)$ & $21 \pm 4(5)^{\circ}$ \\
\hline $3 \mathrm{~d}$ oxic & $61 \pm 24(5)^{\circ}$ & $123 \pm 27(5)^{\circ}$ & $0 \pm 0(5)$ & $18 \pm 13(4)$ \\
\hline 6 d oxic & $78 \pm 37(4)^{\circ}$ & $179 \pm 50(4)^{\circ}$ & $0 \pm 0(4)$ & $39 \pm 24(8)^{\circ}$ \\
\hline
\end{tabular}

\section{Apparent diffusion coefficient and apparent detoxification constant for sulphide}

In order to estimate the rate of sulphide diffusion into the tissues, the apparent diffusion coefficient for total sulphide $(D)$ was calculated by using Eq. (1). The effective radius $\left(r_{\mathrm{e}}\right)$ was estimated by using Eq. (2) with the tissue water content ( $w=0.84$; Bordin et al. 1992) and the average fresh mass $(m)$ of the clams without shells. The half-saturation time $(\tau)$ resulted from linear curve fitting (Eq. 3) of the data of total sulphur concentrations (sum of sulphide, thiosulphate, sulphite, and elemental sulphur by consideration of stoichiometric ratios and control values) in the tissues during oxic-sulphidic incubations. Table 4 shows the corresponding linear equations $f(x)$, the resulting half-saturation times $(\tau)$, the average fresh masses $(m)$, the resulting effective radia $\left(r_{\mathrm{e}}\right)$, as well as the apparent diffusion coefficients (D) for the studied populations. It is obvious that the diffusion coefficients of the sulphide-sensitive populations from Kiel Bight and Dorum-Neufeld were roughly twice as high as those of the sulphide-tolerant populations from Gdańsk Bay and Hiddensee.

Table 4 also shows the maximum sulphide concentrations $\left(c_{\max }\right)$ in the tissues after oxic-sulphidic incubations (cf. Table 3). In the determination of $c_{\max }$ sulphide concentrations of control clams were subtracted since control concentrations are probably not based on free tissue sulphide and would therefore not influence the equilibrium. From $c_{\max }$ the equilibrium sulphide concentrations $\left(c_{i}\right)$ were calculated, assuming tissue water content to be $84 \%$ (Bordin et al. 1992) and density of water to be $1 \mathrm{~kg} \mathrm{l}^{-1}$. These data were required, together with the external sulphide concentration $\left(c_{0}=200 \mu \mathrm{M}\right)$, for the calculation of the apparent detoxification constants ( $k$ ) using Eq. (4). The detoxification constants of the sulphide-sensitive populations were higher than those of the sulphide-tolerant ones (Table 4) 
Table 4. Macoma balthica. Populations from Kiel Bight, Dorum-Neufeld (22\% S), the Gulf of Gdańsk, and Hiddensee ( $9 \%$ S) Calculation of apparent diffusion coefficients $(l)$ ) and detoxification constants $(k)$. Data from oxic incubations at $200 \mu M$ sulphide $\left(10^{\circ}(: \mathrm{pl}\right.$ [ 8.0). For further explanation see 'Results'

\begin{tabular}{|c|c|c|c|c|}
\hline & Kiel & Dorum & Gdańsk & Hiddensee \\
\hline$f(x)=$ & $0.0033 x+0.0024$ & $0.0118 x+0.0045$ & $0.0257 x+0.0048$ & $0.0150 x+0.0026$ \\
\hline$\tau[h]$ & 1.4 & 2.6 & 5.4 & 5.7 \\
\hline$m[\mathrm{mg}]$ & 48 & 150 & 188 & 104 \\
\hline$r_{\mathrm{e}}[\mathrm{cm}]$ & 0.213 & 0.311 & 0.335 & 0.275 \\
\hline$D\left[\mathrm{~cm}^{2} \mathrm{~s}^{-1}\right]$ & $3.0 \times 10^{-6}$ & $3.4 \times 10^{-6}$ & $1.9 \times 10^{-6}$ & $1.2 \times 10^{-6}$ \\
\hline $\begin{array}{l}c_{\max }\left[\mathrm{nmol} \mathrm{g}^{-1} \mathrm{tm}\right] \\
c_{i}[\mu \mathrm{M}]\end{array}$ & $\begin{array}{l}77 \\
92\end{array}$ & $\begin{array}{l}24 \\
29\end{array}$ & $\begin{array}{l}40 \\
48\end{array}$ & $\begin{array}{l}47 \\
56\end{array}$ \\
\hline$k\left[\mathrm{~s}^{-1}\right]$ & $1.5 \times 10^{-4}$ & $2.1 \times 10^{-4}$ & $7.3 \times 10^{-5}$ & $6.2 \times 10^{-5}$ \\
\hline
\end{tabular}

\section{DISCUSSION}

Marine invertebrates living in sulphidic habitats need to exclude hydrogen sulphide from their tissues or to detoxify it. These capacities are species-specific and lead to different niches in the biotope. Our study shows that different degrees of sulphide tolerance not only exist at the spocics lovel but can also be found in different populations of the same species. If oxygen is available, specimens of the Baltic clam Macoma balthica from sulphidic habitats (the Gulf of Gdańsk and shallow waters near Hiddensee) show distinctly higher survival capacities during sulphide exposure than those from low sulphide contaminated environments (Kiel Bight and the Wadden Sea near DorumNeufeld; Fig. 3c). However, there are no differences in tolerance to oxygen deficiency between the different populations (Fig. 3a). Therefore, under hypoxicsulphidic conditions, specimens of the populations do not differ in their tolerances (Fig. 3b). In comparison to other species (e.g. Macoma calcarea), tolerance to oxygen deficiency is relatively high in $M$. balthica (von Oertzen 1973, Dries \& Theede 1974). Yet, its metabolism depends on the degree of oxygen saturation (Dries \& Theede 1976), resulting in change to anaerobiosis (Jahn et al. 1993, Theede et al. 1995, Jahn 1997). When oxygen and sulphide are present simultaneously, it becomes evident that the clams from sulphidic habitats are better able to protect themselves against hydrogen sulphide. Under these conditions, they can survive longer because their energy metabolism is not entirely based on anaerobiosis. On the other hand, when cytochrome coxidase is completely inhibited in clams from sulphide-sensitive populations, oxidative metabolism is prevented. Therefore, these animals die within the same amount of time as under hypoxic conditions.

Cytochrome coxidase from individuals of all studied populations of Macoma balthica is inhibited by very low sulphide concentrations (Table 2). As in other species (Hand \& Somero 1983, Theede et al. 1995), inhibition constants are in the nanomolar range. Therefore, differences in sulphide tolerance do not seem to be correlated with different forms of cytochrome $c$ oxidase. However, differences in enzyme inhibition are found after oxic-sulphidic incubation of living specimens (Fig. 4). In live specimens, specific cytochrome $c$ oxidase activity decreases significantly áfteı líte iirst days of oxic-suiphidic incubatıon un specimens of sulphide-sensitive populations (Kiel Bight, Dorum-Neufeld), whereas it remains relatively constant in sulphide-tolerant clams (Hiddensee, Gdańsk Bay). Obviously, the second group of clams are better able to protect their cytochrome coxidase against toxification by hydrogen sulphide.

The decrease of specific cytochrome $c$ oxidase activity in sulphide-sensitive clams might be caused by reduced enzyme concentrations. The turnover rate of this enzyme in Macoma balthica is not known, but its half-life is reported to be about $30 \mathrm{~h}$ in other species such as the brine shrimp Artemia franciscana (Grieshaber et al. 1994). Maybe the synthesis of cytochrome $c$ oxidase is inhibited in sulphide-sensitive clams in a way comparable to the inhibition of haem synthesis by lead (Kondo et al. 1983). This hypothesis is confirmed by our recovery experiments which show only a slow increase of specific cytochrome $c$ oxidase activity during $9 \mathrm{~d}$ of oxic incubation without sulphide (Fig. 5). It can be assumed that this increase is related to de novo enzyme synthesis during this period.

How can the sulphide-resistent clams protect themselves against hydrogen sulphide? One mechanism to reduce toxic effects of sulphide could be the binding of metal-sulphur precipitations within vesicles in the mantle edge, a phenomenon which was found in Macoma balthica from Hiddensee (Windoffer \& Jahn 1994, $1995)$ and which is comparable to sulphide precipitation in other species (NuB 1984, Levitt \& Arp 1991, Oeschger \& Janssen 1991, Jahn et al. 1992, Janssen \& Oeschger 1992, Oeschger \& Pedersen 1994, Dubilier et al. 1995). Yet, calculations on sulphide diffusion 
demonstrated that metal stocks in the tissues will be exhausted very quickly (Jahn 1997). Therefore, this protection is probably only effective for a short time at the beginning of sulphide exposure as shown for the oligochaete Tubificoides benedii (Dubilier et al. 1995).

The oxidation of hydrogen sulphide to non-toxic compounds seems to be the more important alternative. If oxygen is available, the clams from all studied habitats are able to produce high amounts of thiosulphate (Fig. 7b). Other products such as sulphite and elemental suiphur are of minor significance (Table 3 ). Production of elemental sulphur could be demonstrated so far only in few species (Powell et al. 1980, D. Nielsen pers. comm., F. Thiermann pers. comm.). Sulphite is considered as an intermediate oxidation product (O'Brien \& Vetter 1990), whereas thiosulphate has been reported for several marine invertebrates to be the main oxidation product (Vismann 1991a, Jahn et al. 1992, 1996, Oeschger \& Vetter 1992, Volkel \& Grieshaber 1992, Hagerman \& Vismann 1993, Johns et al. 1997)

Sulphide oxidation depends on the availability of oxygen. By means of a siphon, Macoma balthica is able to pump water from above the sediment through its gills and extract oxygen from it, even at high sulphide concentrations in the sediment. Under hypoxic conditions, internal oxygen stores are quickly consumed, followed by lower thiosulphate production and higher accumulation of sulphide in the tissues, especially in the sulphide-sensitive clams from Kiel Bight (Fig. 6a).

The ratio of sulphide diffusion to oxidation is crucial for the efficiency of sulphide detoxification. Therefore, sulphide influx data in specimens of the different populations of Macoma balthica were used for an estimation of the diffusion coefficients and the detoxification constants for total sulphide. These values take into account sulphide diffusion through all diffusion barriers and all detoxification processes in the tissues. Therefore, they are 'apparent' values, comparable with the apparent Michaelis-Menten constant (Jahn et al. 1996, 1997, Jahn 1997). In comparison to diffusion coefficients for soft-bodied macrofauna species (Julian \& Arp 1992, Völkel \& Grieshaber 1992), the apparent diffusion coefficients for the populations of $M$. balthica (1.2 to $3.4 \times 10^{-6} \mathrm{~cm}^{2} \mathrm{~s}^{-1}$; Table 4 ) are relatively low. For the ostracod Cyprideis torosa, living in high sulphidic habitats (Gamenick et al, 1996), an apparent diffusion coefficient of only $8.1 \times 10^{-7} \mathrm{~cm}^{2} \mathrm{~s}^{-1}$ was found ( Jahn et al. 1996), which is even lower than the coefficients for the populations of $M$. balthica. Although there are some limits to the degree to which the different diffusion coefficients can be compared (cf. Jahn et al. 1996, 1997), it seems plausible that species with shells are able to reduce sulphide diffusion by temporary reduction of valve opening.
Sulphide diffusion is manifested differently in the populations of Macoma balthica (Table 4). Due to relatively high variations in the concentrations of sulphur compounds, the calculated apparent diffusion coefficients give only a hint of sulphide influx rates. A comparison of the populations shows, however, that the coefficients of the sulphide-sensitive clams from Kiel Bight and Dorum-Neufeld are about twice as high as those of the sulphide-tolerant specimens from Gdańsk Bay and Hiddensee. Obviously, sulphide penetrates faster into the sulphide-sensitive clams. This is also demonstrated by the distinctly shorter half-saturation times. The lowest diffusion coefficient was found in the Hiddensee population. Hence, these clams are able to exclude hydrogen sulphide most efficiently, maybe by means of behavioural adaptations like stronger reduction of valve opening or longer shell closure periods.

Due to faster influx of hydrogen sulphide, the sulphide-sensitive clams from Kiel Bight and Dorum need faster detoxification. This becomes evident in the higher detoxification constants as compared to those of the clams from Gdansk Bay and Hiddensee (Table 4). In spite of accelerated detoxification, the internal sulphide level cannot be kept low in sulphide-sensitive clams during longer sulphide exposure and the metabolism may be negatively affected. The resulting higher stress on metabolism would finally lead to a lower survival capacity under sulphidic conditions. On the other hand, the lower detoxification constants of the sulphide-tolerant clams show that their metabolism is stressed less. Thus, these clams are better adapted to their sulphidic habitats. The different ability to reduce sulphide diffusion is probably one explanation for the differences in sulphide tolerance of the populations of Macoma balthica.

The different reactions of the populations of Macoma balthica to hydrogen sulphide lead to the question of whether these reactions are genetically determined or induced by individual adaptation. $M$. balthica shows a high genetic variability (Meehan 1985), and genetic differences between populations in the Baltic Sea have also been reported (Väinölä \& Varvio 1989). In the laboratory, clams from Hiddensee and Gdańsk do not lose their high sulphide tolerance when kept under oxic conditions for at least 3 mo (Theede et al. 1995, Jahn 1997). This suggests that there is a genetic component involved in high sulphide tolerance. On the other hand, a phenotypic adaptation to hydrogen sulphide was shown in clams from Kiel Bight after a slow increase in the sulphide concentration in the incubation medium over a period of 14 d (Jahn 1997). Similar results were obtained in the California killifish Fundulus parvipinnis by Bagarinao \& Vetter (1993). In this species, sulphide tolerance did not diminish in fish held in sulphide-free water but could be improved by 
prior acclimation to sulphidic conditions. Obviously, genetic studies of populations of $M$. balthica are necessary to elucidate this problem.

In conclusion, our study shows that different degrees of sulphide tolerance are found not only at the species but also at the population level. Hydrogen sulphide can probably be considered an important factor influencing species evolution. Finally, it has to be emphasized that it is not possible to draw conclusions for an entire species by investigating only specimens from one single population. This has to be taken into account in further ecophysiological studies.

Acknowledgements. This study was funded by the German Bundesminister für Bildung, Wissenschaft, Forschung und Technologie (BMBF) as part of the joint research programme on suiphide and methane biotopes in the Baltic and North Sea ('DYSMON II'- 03F0123D) and the German-Polish cooperation programme WTZ (Projekt X087.1). The experiments with clams from the Gulf of Gdańsk were carried out in co-operation with Urszula Janas and Prof. A. Szaniawska. We are grateful to Kathrin Meyer and Dr Boris Culik for their comments on an earlier draft of the manuscript.

\section{LITERATURE CITED}

Arp A.J, Hansen BM, Julian D (1992) Burrow environment and coelomic fluid characteristics of the echiuran worm Urechis caupo from populations at three sites in northern California. Mar Biol 113:613-623

Babenerd B (1991) Increasing oxygen deficiency in Kiel Bay (Western Baltic). A paradigm of progressing coastal eutrophication. Meeresforschung 33:121-140

Bagarinao T (1992) Sulficle as an environmental factor and toxicant: tolerance and adaptations in aquatic organisms Aquat Toxicol 24:21-62

Bagarinao T, Vetter RD (1993) Sulphide tolerance and adaptation in the California killifish, Fundulus parvipinnis, a salt marsh resident. J Fish Biol 42:729-748

Beukema JJ, Meehan BW (1985) Latitudinal variation in linear growth and other shell characteristics of Macoma balthica. Mar Biol 90:27-33

Bonsdorff E, Norkko A, Boström C (1995) Recruitment and population maintenance of the bivalve Macoma balthica (L.)--factors affecting settling success and early survival on shallow sandy bottoms. In: Eleftheriou A, Ansell AD, Smith CJ (eds) Biology and ecology of shallow coastal waters. Proceedings of the 28th European Marine Biology Symposium. Iraklio, Crete, 1993. Olsen \& Olsen, Fredensborg, p 253-260

Bordin G, McCourt J, Rodríguez A (1992) Trace metals in the marine bivalve Macoma balthica in the Westerschelde Estuary (The Netherlands). Part 1: Analysis of total copper, cadmium, zinc and iron concentrations-locational and seasonal variations. Sci Total Environ 127:255-280

Bradford MM (1976) A rapid and sensitive method for the quantitation of microgram quantities of protein utilizing the principle of protein-dye binding. Anal Biochem 72: $248-254$

Cline JD (1969) Spectrophotometric determination of hydrogen sulfide in natural waters. Limnol Oceanogr 14 : $454-485$
Dries RR, Theede H (1974) Sauerstoffmangelresistenz mariner Bodenevertebraten aus der Westlichen Ostsee. Mar Biol $25: 327-333$

Dries RR, Theede H (1976) Stoffwechselintensität und Reservestoffabbau einıger mariner Muscheln bel herabgesetzter Sauerstoffsättigung des Mediums. Kieler Meeresforsch Sonderh 3:37-48

Dubilier N, Giere O, Grieshaber MK (1995) Morphological and ecophysiological adaptations of the marine oligochaete Tubificoides benedii to sulfidic sediments. Am Zool 35:163-173

Fenchel TM, Riedl RJ (1970) The sulfide system: a new biotic community underneath the oxidized layer of marine sand bottoms. Mar Biol 7:255-268

Gamenick I, Giere O (1994) Population dynamics and ecophysiology of Capitella capitata from North Sea intertidal flats: evidence for two sibling species. Polychaete Res 16: $44-47$

Gamenick I., Giere O (1996) Differentiation of the Capitella capitata (Polychaeta) complex using ecophysiological and electrophoretical methods. Verh Dtsch Zool Ges 89.1:10

Gamenick I, Jahn A, Vopel K, Giere O (1996) Hypoxia and sulphide as structuring factors in a macrozoobenthic community on the Baltic Sea shore: colonisation studies and tolerance experiments. Mar Ecol Prog Ser 144:73-85

Giere O (1992) Benthic life in sulfidic zones of the sea - ecological and structural adaptations to a toxic environment. Vern Dtsch Zool Ges 85:2:77-93

Grieshaber MK, Hardewig I, Kreutzer U, Pörtner HO (1994) Physiological and metabolic responses to hypoxia in invertebrates. Rev Physiol Biochem Pharmacol 125:43-147

Grieshaber MK, Hardewig I, Kreutzer U, Schneider A, Volkel $S$ (1992) Hypoxia and sulfide tolerance in some marine invertebrates. Verh Dtsch Zool Ges 85.2:55-76

Günther CP (1991) Settlement of Macoma balthica on an intertidal sandflat in the Wadden Sea. Mar Ecol Prog Ser $76: 73-79$

Hagerman L, Vismann B (1993) Anaerobic metabolism, hypoxia and hydrogen sulphide in the brackish water isopod Saduria entomon (L.). Ophelia 38:1-11

Hand SC, Somero GN (1983) Energy metabolism pathways of hydrothermal vent animals: adaptations to a food-rich and sulfide-rich deep-sea environment. Biol Bull (Woods Hole) 165:167-181.

Howes BL, Dacey JWH, Wakeham SG (1985) Eftects of sampling technique on measurements of porewater constituents in salt marsh sediments. Limnol Oceanogr 30(1): $221-227$

Huxtable RJ (1986) Biochemistry of sulfur. Plenum Press, New York

Ingvorsen K, Jørgensen BB (1979) Combined measurement of oxygen and sulfide in water samples. Limnol Oceanogr $24(2): 390-393$

Jahn A (1997) Ökophysiologische Untersuchungen an Macoma balthica (Bivalvia) und Cyprideis torosa (Ostracoda) uber Anpassungen an den Umweltfaktor Schwefelwasserstoff. Berichte IfM Kiel Nr 289 (PhD thesis, University of Bremen)

Jahn A, Gamenick I, Theede H (1996) Physiological adaptations of Cyprideis torosa (Crustacea, Ostracoda) to hydrogen sulphide. Mar Ecol Prog Ser 142:215-223

Jahn A. Janas U, Theede H, Szaniawska A (1997) Significance of body size in sulphide detoxification in the Baltic clam Macoma balthica (Bivalvia, Tellinidae) in the Gulf of Gdansk. Mar Ecol Prog Ser 154:175-183

Jahn A, Oeschger R, Theede H (1992) Auswirkungen von Schwefelwasserstoff auf den Stoffwechsel ausgewählter 
Polychaeten aus der Nord- und Ostsee. Verh Dtsch Zool Ges 85.1:22

Jahn A, Theede H, Oeschger R (1993) Unterschiedliche Fähıkeiten zur Schwefelwasserstoffentgiftung bei Populationen von Macoma balthica. Verh Dtsch Zool Ges 86.1:94

Janas U, Szaniawska A (1996) The influence of hydrogen sulphide on macrofaunal biodiversity in the Gulf of Gdańsk. Oceanologia 38(1):127-142

Janssen HF, Oeschger R (1992) The body wall of Halicryptus spinulosus (Priapulida) - ultrastructure and changes induced by hydrogen sulfide. Hydrobiologia 230:219-230

Job D, Cochet C, Dhien A, Chambez EM (1978) A rapid method for screening inhibitor effects: determination of $I_{50}$ and its standard deviation. Anal Biochem 84:68-77

Johns AR, Taylor AC. Atkinson RJA, Grieshaber MK (1997) Sulphide metabolism in thalassinidean Crustacea. J Mar Biol Assoc UK 77:127-144

Jorgensen BB (1977) The sulfur cycle of a coastal marine sediment (Limfjorden, Denmark). Limnol Oceanogr 22:814 -832

Jergensen BB (1990) A thiosulfate shunt in the sulfur cycle of marine sediments. Science 249:152-154

Jørgensen BB, Fenchel T (1974) The sulfur cycle of a marine sediment model system. Mar Biol 24:189-201

Julian D. Arp AJ (1992) Sultide permeability in the marine invertebrate Urechis caupo. J Comp Physiol B 162:59-67

Kondo M, Kajimoto M, Urata G (1983) Alteration of activities of $\delta$-aminolevulinic acid synthase, $\delta$-ammolevulinic acid dehydratase and $\delta$-aminolevulinıc acid dehydratase inhibitor in the bone marrow cells of lead poisoned rats. Exp Hermatol 11(4):324-331

Lauren DR, Watkinson JH (1985) Elemental sulphur analysis using high-performance liquid chromatography on 10- $\mu \mathrm{m}$ rigid polymer partıcles. J Chromatogr 348:317-320

Levitt JM, Arp AJ (1991) The effects of sulfide on the anaerobic metabolism of two congeneric species of mudflat clams. Comp Biochem Physiol 98B:339-347

Meehan BW (1985) Genetic comparison of Macoma balthica (Bivalvia, Telinidae) from the eastern and western North Atlantic Ocean. Mar Ecol Prog Ser 22:69-76

Meyers MB, Fossing H, Powell EN (1987) Microdistribution of interstitial meiofauna, oxygen and sulfide gradients, and the tubes of macro-infauna. Mar Ecol Prog Ser 35:223-241

Miron G. Kristensen E (1993a) Behavioural response of three nereid polychaetes to injection of sulfide inside burrows Mar Ecol Prog Ser 101:147-155

Miron G, Kristensen E (1993b) Factors influencing the distribution of nereid polychaetes: the sulfide aspect. Mar Ecol Prog Ser 93:143-153

Newton GL, Dorian R, Fahey RC (1981) Analysis of biological thiols: derivatization with monobromobimane and separation by reverse-phase high-performance chromatography. Anal Biochem 114:383-387

Nicholls P (1975) The effect of sulphide on cytochrome das isosteric and allosteric shitts of the reduced $\alpha$-peak. Biochim Biophys Acta 396:24-35

Nicholls P. Kim JK (1981) Oxıdation of sulphide by cytochrome $a a_{3}$. Biochim Biophys Acta 637:312-320

Nicholls P, Kim JK (1982) Sulphide as an inhibitor and electron donor for the cytochrome $c$ oxidase system. Can J Biochem 60:613-623

Norkko A, Bonsdorff E (1996) Altered benthic prey-availabiluty due to episodic oxygen deficiency caused by drifting algal mats. PSZN I: Mar Ecol 17(1-3):355-372

Nuß B (1984) Ultrastrukturelle und ökophysiologische Untersuchungen an kristalloiden Einschlüssen der Muskeln emes sulfidtoleranten limnischen Nematoden (Tobrilus gracilis). Veröff Inst Meeresforsch Bremerhav 20:3-15
O'Brien J, Vetter RD (1990) Production of thiosulphate during sulphide oxidation by mitochondria of the symbiontcontanning bivalve Solemyd reidi. J Exp Biol 149:133-148

Oertzen JA von (1973) Abiotic polency and physiological resistance of shallow and deep water bivalves. Oikos (Suppl) 15:261-266

Oeschger R, Janssen HH (1991) Histological studies on Hallcryptus spinulosus (Priapulida) with regard to environmental hydrogen sulfide resistance. Hydrobıologia 222:1-12

Oeschger $R$, Pedersen TF (1994) Influence of anoxia and hydrogen sulphide on the energy metabolism of ScrobicuJaria plana (da Costa) (Bivalvia). J Exp Mar Biol Ecol 184: 255-268

Oeschger R, Tschischka K (1995) Bedeutung der mitochondrialen Sulfidoxidation bei nereiden Polychaeten. Verh Dtsch Zool Ges 88.1:69

Oeschger R, Vetter RD (1992) Sulfide detoxification and tolerance in Halicryptus spinulosus (Priapulida): a multiple strategy. Mar Ecol Prog Ser 86:167-179

Powell E (1989) Oxygen, sulfide and diffusion: why thiobiotic meiofauna must be sulfide-insensitive first order respirers. J Mar Res 47:887-932

Powell EN, Crenshaw MA, Rieger RM (1980) Adaptations to sulfide in sulfide-system meiofauna. Endproducts of sulfide detoxification in three turbellarians and a gastrotrich. Mar Ecol Prog Ser 2:169-177

Prena J (1994) Oxygen depletion in Wismar Bay (Western Baltic Seaj 1988. Arch Fish Mar Res 42(1):77-87

Revsbech NP, Jurgensen BB, Blackburn TH (1980) Oxygen in the sea bottom measured with a microelectrode. Science 207:13.55-1356

Somero GN, Childress JJ, Anderson AE (1989) Transport, metabulism, and detoxification of hydrogen sulfide in animals from sulfide-rich marine environments. CRC Crit Rev Aquat Sci 1:591-614

Steudel R, Göbel T, Holdt G (1988) The molecular composltion of hydrophilic sulfur sols prepared by acid decomposition of thiosulfate. Z Naturforsch 43b:203-218

Steudel R, Holdt G, Göbel T, Hazeu W (1987) Chromatographische Trennung höherer Polythionate $\mathrm{S}_{n} \mathrm{O}_{6}{ }^{2-}(\mathrm{n}=$ 3...22) und deren Nachweis in Kulturen von Thiobacillus ferrooxidans; molekulare Zusammensetzung bakterieller Schwefelausscheidungen. Angew Chem 99(2):143-146

Theede $H$ (1973) Comparative studies on the influence of oxygen deficiency and hydrogen sulphide on marine bottom invertebrates. Neth J Sea Res 7:244-252

Theede H, Oeschger R, Jahn A (1995) Adaptive responses of marine benthic invertebrates to hydrogen sulphide. In: Eleftheriou A. Ansell AD, Smith CJ (eds) Biology and ecology of shallow coastal waters. Proceedings of the 28th European Marine Biology Symposium. lraklio, Crete, 1993. Olsen \& Olsen, Fredensborg, p 149-152

Theede H, Ponat A, Hırokı K, Schlieper C (1969) Studies on the resistance of marine bottom invertebrates to oxygendeficiency and hydrogen sulphide. Mar Biol 2:325-337

Tschischka K, Oeschger R (1995) Mitochondrial sulphide oxidation in selected manne invertebrates. Proceedings of the 4 th International Congress of Comparative Physiology and Biochemistry. Physiol Zool 68(4):135

Väinölä R, Varvıo SL (1989) Biosystematics of Macoma balthica in northwostern Europe. In: Ryland JS, Tyler PA (eds) Reproduction, genetics and distributions of marine organisms. Proceedings of 23rd European Marine Biology Symposium. Olsen \& Olsen, Fredensborg, p 309-316

Vetter RD, Matrai PA, Javor B, O'Brien J (1989) Reduced sulfur compounds in the marine environment. Analysis by high-performance liquid chromatography. In: Saltzman 
ES, Cooper WJ (eds) Biogenic sulfur in the environment. ACS Symposium Series 393. American Chemical Society, Washington, DC, p 243-261

Vismann B (1990) Sulfide detoxification and tolerance in Nereis (Hediste) diversicolor and Nereis (Neanthes) virens (Annelida: Polychaeta). Mar Ecol Prog Ser 59:229-238

Vismann B (1991a) Physiology of sulfide detoxification in the isopod Saduria (Mesidothea) entomon. Mar Ecol Prog Ser $76: 283-293$

Vismann B (1991b) Sulfide tolerance: physiological mechanisms and ecological implications. Ophelia 34:1-27

Völkel S, Grieshaber MK (1992) Mechanisms of sulphide tolerance in the peanut worm. Sipunculus nudus (Sipunculidae) and in the lugworm. Arenicola marina (Polychaeta). J Comp Physiol B 162:469-477

Weigelt $M(1990)$ Oxygen conditions in the deep water of Kiel Bay and the impact of inflowing salt-rich water from the Kattegat. Meeresforschung 33:1-22

This article was submitted to the editor
Weigelt M (1991) Short-and long-term changes in the benthuc community of deeper parts of Kiel Bay (Western Baltic) due to oxygen depletion and eutrophication. Meeresforschung 33:197-224

Widdel F (1988) Microbiology and ecology of sulfate- and sulfur-reducing bacteria. In: Zehnder AJB (ed) Biology of anaerobic microorganisms. John Wiley \& Sons, New York, p $469-585$

Windoffer R, Jahn A (1994) Morphologische und physiologische Untersuchungen zur $\mathrm{H}_{2} \mathrm{~S}$-Toleranz von Macoma balthica (Bivalvia, Tellinidae). Verh Dtsch Zool Ges 87.1: 209

Windoffer R, Jahn A (1995) Untersuchungen zur Sulfidtoleranz von Macoma balthica. BODDEN 2:235-238

Włodarska-Kowalczuk M. Janas U, Szaniawska A (1996) Hydrogen sulphide and other factors influencing the macrobenthic community structure in the Gulf of Gdanisk. Oceanologia 38(3):379-394

Manuscript received: March 17, 1997

Revised version accepted: May 22, 1997 